\title{
On Love and Concupiscence: On the Virtue of Levinasian Love Over Hegelian Love
}

\author{
RYLIE J OHNSON
}

Levinas' criticisms of Hegel are well known. Hegel's thinking attempts to achieve totality through absolute knowledge, which is opposed to Levinas' argument that there is an infinity, reflected in the face of the Other, that cannot be articulated within a total system. Specifically, Levinas argues against Hegel's position that we can only achieve an ethical relationship with the other when everyone is universally recognized within a total State. For Levinas, it is impossible to fully recognize the other since they are transcendent, or absolutely Other, and it is in this lack of recognition that we find the origin of ethics.

But, one can object that Levinas' criticisms do not do justice to Hegel's position. It is the contention of this paper that Levinas only looks at one aspect of Hegelian recognition, the political, and avoids the other, love. For it is not simply an "impersonal reason" that constitutes recognition, but our affective relationships with others, experienced as love. This is not to say that Levinas' critique of Hegel is wrong, rather it is one-sided. It remains the case that Hegel's love is the means of achieving unity between the self and other, constituting a totality. In this regard Hegel's account of love encompasses what Levinas would consider a negative manifestation of love. In his Totality and Infinity, Levinas claims that love is ambiguous. On the one hand, love can relate to the Other as transcendent; on the other, it can relate to the Other as immanent and try to reduce it to the same: "Love as a relation with the Other can be reduced to this fundamental immanence, be divested of all transcendence, seek but a connatural being, a sister soul, present itself as incest" (Levinas TI 254). It will be argued that Hegelian love is a manifestation of this latter sense.

The project of the essay will be two-fold. First, we will reveal the one-sided character of Levinas' account of Hegelian recognition by exploring the centrality of love in the latter's work. Second, we will expand Levinas' critique to encompass Hegelian love. It will be argued that from a Levinasian perspective Hegel's account of love is not a sufficient ground for ethics. We will begin by examining Levinas' criticisms of Hegel. Here we will see how recognition is achieved in the 
State at the detriment of our ethical relations with the Other. Then we will turn to the status of love in Hegel's work. Our argument will be largely pooled from Alice Ormiston's Love and Politics: re-interpreting Hegel, in which she argues that the concept of love dominates the whole of Hegel's work. Indeed, her more radical claim is that the movement towards absolute knowledge, "presupposes the knowledge of love and is driven forward by this knowledge" (Ormiston, 36).

From here we will turn to Levinas' account of love as a means to criticize Hegelian love. Ultimately, we will argue that Levinasian love fosters a greater, more radical potency for ethical responsibility than Hegelian love. We will do this by presenting to accounts of love in Levinas' work. There are two forms love, ethical and erotic. The former refers to the ethical responsibility that we feel for the Other, and the latter refers to the sexual love of the couple. While Levinas argues that these two modalities of love are separate, we will argue that they are compatible to the extent that erotic love allows for the creation of the Child, a new irreducible, Other from which ethical responsibility is engendered. Broadly construed, the creation of children constitutes the continuation of a larger society where ethical responsibility is fostered. From these considerations, it will be argued that Levinas' love is more radical since it accounts for the communal love necessary for social life, while also not reducing the Other to society. For Levinas, love of the Stranger as such is the highest form of love.

\section{Hegel in Totality and Infinity ${ }^{1}$}

Both Levinas and Hegel claim that the Other constitutes the identity of the self, and is encountered through Desire. But, it is also through Desire that we find a divergence between them. For Hegel, Desire is satisfied through the mutual recognition of the "I" and Other; whereas Levinas sees that Desire cannot be satisfied, on the condition that the other is radically Other. In this section we will focus on Levinas' critique of Hegel's notion of Desire as desiring recognition, which reveals three major points of contention: Hegel's argument that (1) all intersubjective relationships begin with violence and domination, which (2) is resolved in the State; and (3) that this process of resolution possesses an historical telos.

In the Phenomenology of Spirit, Hegel claims that "selfconsciousness exists in and for itself when, and by the fact that, it so exits

\footnotetext{
${ }^{1}$ Although this essay focuses almost exclusively on Totality and Infinite, it is important to also acknowledge that many of these similar themes are carried forward in his later book Otherwise Than Being, or Beyond Essence. However, in the later text, Levinas focuses more on giving an account of the moral repercussions of encountering the Other (Levinas $O B$ xii). Accordingly, the text is more concerned with justice and law.
} 
for another" (Hegel PS 111). Here we see Hegel's notion of "Recognition:" the "I" can only achieve self-certainty through being recognized by another. As an end that self-consciousness pursues, recognition is a Desire that only the other can satisfy (109-110). Hegel argues that the "I" lives through negating objects (i.e., consuming foods). This has the dual result of maintaining the "I" as a living organism and giving it a sense of self-certainty (109). However, when the "I" meets another self-consciousness it discovers a problem: with its own negating freedom, the other resists negation. This resistance puts into question the certitude of the "I," producing the Desire to be recognized as independent; trying to assert their independence, the two "I's" engage in a "life-anddeath struggle" (114). However, murdering the other, the "I" finds its Desire unsatisfied: there is no one there to recognize her. In order to be recognized, the "I" must subjugate the other, who allows this subjugation for fear of death, resulting in an unequal structure in which both the "I" and other are "opposed to one another, one being only recognized, and the other only recognizing" (112-113). Hegel calls the former the "lord" and the latter the "bondsman."

Yet, this recognition remains unsatisfactory. While the lord is recognized as independent and enjoys the fruit of the bondsman's labor, it is actually the bondsman who is freer than the lord, since the latter is dependent upon the former. Hence: "The truth of the independent consciousness is accordingly the servile consciousness of the bondsman" (117). This results in a contradiction: the lord is recognized and free, but dependent, while the bondsman is recognizing and enslaved, but independent. Both are free and un-free in their own ways. Thus, the only way for them to achieve real freedom is through "recognizing themselves as mutually recognizing one another" (112).

According to Alexandre Kojève interpretation of the Phenomenology, the lord/bondsman opposition is overcome in the universal State, where each individual is recognized as an independent, rights possessing citizen (Kojève 69). ${ }^{2}$ This mutual recognition results in Hegel's notion of "spirit." Hegel describes Spirit as the "absolute substance which is the unity of the different independent selfconsciousness which, in their opposition, enjoy perfect freedom and independence: ' $\mathrm{I}$ ' that is 'we' and 'we that is 'I"' (Hegel PS 110). The universal State is the realization of Spirit. But, possessing rights remains abstract; it is not a concrete manifestation of Spirit. Concrete Spirit is

\footnotetext{
${ }^{2}$ Alexander Kojève's lectures on Hegel had a profound impact on how Hegelian thought would be disseminated in France. This is in part due to the later notoriety of those who attended his lectures, like Jacques Lacan and Merleau-Ponty. It is also believed that Emmanuel Levinas attended, and if he did not it is nonetheless likely that his interpretation is bound up with Kojève's lectures (Moyn, 109).
} 
realized in the mutual labor of the community, each laboring for others (213). This labor includes the active respect and enforcement of legal rights within the community. Hence, Hegel claims that Spirit is the "ethical life of a nation" (265).

Thus, we see that for Hegel intersubjective relationships begin with violence and ends peacefully in the ethical State, where each citizen is recognized as free. It is precisely these two factors that Levinas will criticize. However, there is one last aspect that we shall briefly cover. For Hegel, the process of towards the State is necessary and rational. Hence, the Phenomenology depicts how Spirit "develops itself" historically towards mutual recognition (21). History itself is not random but follows a teleological pattern, which is "comprehended" in the actualization of Spirit.

Against Hegel, Levinas argues, "War presupposes peace, the antecedent and non-allergic presence of the Other; it does not represent the first event of the encounter" (Levinas TI 199). By arguing that the encounter between the "I" and the Other begins with peace, Levinas not only undermines Hegel's position that intersubjectivity begins with violence, but also that history must take shape violently. But, what are we to understand by Levinas' understanding of peace, and why it precedes the possibility of violence? Levinas' account of peace rests on his understanding of Desire and infinity, both of which are essential to his ethics.

Granted that Hegel's concept of desire leads to violence, Levinas' sense of peace must involve a different understanding of Desire. For Levinas, Desire is not for recognition, but to do good for the Other. Desire is not self-interested, but "perfectly disinterested - goodness" (50). The reason for this lays in the fact that Levinas corresponds Desire with infinity: "The idea of infinity is a thought which at every moment thinks more than it thinks. A thought that thinks more than it thinks is a desire" (Levinas CP 56). In Totality and Infinity, Levinas claims that Desire "is desire for the absolutely other," it is absolute in the sense that it is unconditioned and therefore infinite (Levinas TI 34). Thus, as the cause of Desire, the Other is infinite.

How do we know that the Other is infinite? To use Levinas' example, the infinite transcendence of the Other is phenomenologically revealed when the Other teaches us something. This shows the there is potentially always more to learn from the Other, making it impossible to "thematize" the Other into a totality $(67,86,171)$. Thus, at the heart of Levinas' project is an asymmetry between the self and the Other, which cannot be sublimated into a totality.

Why does the infinitude of the Other necessitate the Desire to do goodness? Appealing to the Greek tradition, Levinas' sense of "Good" is 
infinite, perfect and transcendent over the realm of being. As such, the Good is not something that we "lack" or "need," since its transcendence makes it impossible for us to ever fulfill the need. For this reason, Levinas calls the Good a "luxury with respect to needs" (Levinas TI 103). On this point, we can locate an essential difference between Hegel and Levinas. Hegel's Desire indicates a lack within humanity that it seeks to satisfy through consumption and negation. This lack is operative even in our relationships with other people, whom we seek to also consume or negate, or in the case of the lord and bondsman, dominate. For Levinas, however, the infinite transcendence of the Other means that we cannot negate them. Our Desire for the infinite Other corresponds to the Desire for the Good, and therefore we seek to preserve them in their Goodness by doing Good for them. ${ }^{3}$ For Levinas, violence is antithetical to Desire.

With all this in mind, we can properly characterize Levinas' sense of ethics. Unlike Hegel's argument that ethics is the result of mutual recognition, Levinas thinks that ethics is at the very beginning of our social relationships. Specifically, ethics begins by encountering the infinite "face" of the Other, which calls us to do good. ${ }^{4}$ Moreover, the "epiphany" of the encounter with the Other's face reveals the freedom of the "I," rather than threatening it: "The presence of the Other...does not clash with freedom but invests it" (88). But, the investment is not wholly positive. By recognizing their freedom, the "I" realizes that its freedom is potentially violent insofar as it has the freedom to do violence to the Other. For Levinas, the experience results in "shame," by which the "I" sees itself as potentially murderous (Levinas $C P$ 58). This shame is the origin of morality: "Morality begins when freedom, instead of being justified by itself, feels itself to be arbitrary and violent" (Levinas TI 84). What is interesting about this passage is that it inverts the Hegelian account of freedom and violence. For Hegel, the encounter with the other is violent because the other threatens the "I's" freedom. However, for Levinas, the

\footnotetext{
${ }^{3}$ It is important to note that there is a necessarily theological implication to Levinas' argument. The infinite Good, as the "desirable," refers to God. Levinas writes, "The desirable is intangible and separates itself form the relationship with desire which it calls for; through this separation or holiness it remains a third person, the he (God) in the depth of the you. He is good in just this eminent sense; He does not fill me up with goods, but completes me to goodness, which better than goods received" (Levinas CP 165). In Totality and Infinity, Levinas will claim that the face-to-face relationship with the Other reveals the presence of God: "The other is not the incarnation of God, but precisely by his face, in which he is disincarnate, is the manifestation of the height in which God is revealed" (Levinas TI 79).

${ }^{4}$ It is important to note that Levinas will later argue that the "face" is unrepresentable. "The face of a neighbor signifies for me an unexceptionable responsibility, preceding every free consent, every pact, every contract. It escapes representation; it is the very collapse of phenomenality" (Levinas $O B$ 88).
} 
Other makes possible the awareness of our freedom in the first place, rather than threatening it.

At this point, the "I" has the freedom to hurt the Other or to do good for the Other. If the "I" chooses to not harm the Other, who ironically has revealed the very possibility of this choice, then they must still recompense for their shame. This is to say that, as recompense, the "I" feels the ethical responsibility to do justice to the Other $(215){ }^{5}$ But, since the Other is infinite, this responsibility is also infinite; it is "increasing in the measure that it is assumed." Levinas claims that "the more I am just the more guilty I am" (244). Moreover, the "I" is not just responsible to the other, but for the Other. As James Mensch describes: "taking responsibility for the Other's responsibility, I engage myself to fulfill his responsibility, that is, to undo the harm that his actions have caused" (Mensch 147). Ultimately, the Desire to good for the Other - ethics - is manifest in infinite responsibility, by which the "Other counts more than myself” (Levinas TI 247).

Levinas' account of ethics articulates why war, or violence, presupposes peace. Levinas claims that war rests on the fact that the Other, in this case the antagonist or opponent, is free and transcends our power: "War presupposes the transcendence of the antagonist; it is waged against man" (222). Accordingly, in order for there to be an antagonist that transcends the "I," the "I" must already have encountered the Face of the infinite, transcendent Other. A peaceful encounter precedes the possibility of violence and war. In fact, for Levinas, the infinity discovered in the Other's face immediately prohibits violence and demands the maintenance of peace: "This infinity, stronger than murder (which is necessarily negative), already resists us in his face, is his face, is the primordial expression, is the first word: 'you shall not commit murder"' (199). ${ }^{6}$

The peacefulness of the first encounter is best expressed in Levinas' account of the parent-child relationship. ${ }^{7}$ While we will go into more detail about this relationship later in the essay, some remarks are important to make to fully flesh out the nature of Levinas' ethics. It is the child, as Other, who teaches and invests the parents freedom and ethical responsibility. Parents exist in an essentially "protective" relationship with the child (278). In a sense, the parent-child relationship inverts the

\footnotetext{
${ }^{5}$ In Otherwise than Being, Levinas claims that the primary responsibility is for the Other's freedom. "Responsibility prior to any free commitment, the oneself outside of all the tropes of essence, would be responsibility for the freedom of the others" $[O B, 109]$.

${ }^{6}$ In Otherwise Than Being Levinas' account of encountering the face of the Other is still peaceful, but it is traumatic for the "I" (Levinas $O B$ 12).

${ }^{7}$ We will use the term parent, rather than Levinas' paternal emphasis on the father's relationship to the child.
} 
Hegelian master-slave relationship, whereby the "I," as parent, is the bondsman who has their identity and freedom invested and affirmed in the child who plays the role of master. ${ }^{8}$ This relationship will be further examined when we turn to Levinas' account of love.

Thus, we can conclude this section by arguing that by positing the asymmetry between the "I" and the Other, Levinas affirms the freedom of both, and their ethical responsibilities, without appealing to mutual recognition or relying on the necessity of violence. In this way, Levinas also undermines Hegel's appeal to the State and History. The State is, for Levinas, totalitarian, because it effaces the alterity of the Other. However, the State is impossible to maintain. Given that the Other cannot be thematized, there always exists in the State a "surplus" of society, a multiplicity of Others, who can resist (220-221). Likewise, Levinas argues that the Other has the "power to break the continuity of being or of history" (195).

\section{Hegelian Love}

Levinas' primary argument that Hegel's State, and even his system as a whole, is totalitarian is in many respects valid. Hegel, for instance, argues that individual action, compared to State action, is "so insignificant that it hardly worth talking about" (Hegel PS 255). That being said, Levinas is also unfair to Hegel's ethical position. Robert Williams argues that Hegel's ethical life is "a non-totalitarian, articulated totality that liberates, preserves, and safeguards freedom and alterity (412). The reason for this rests in the fact that the ethical life of the State is not founded on mutual recognition alone, but also requires love, which serves as the "foundation of an ethical life" (Hegel $P R \S 175$ ).

The State requires love to realize a true ethical community. Abstractly, the State grants rights upon the "I." But, these abstract rights do not confer the moral obligation that citizens should feel towards each other as members of a larger community. For, Hegel it is only through concrete ethical practices that these ideas can become truly inalienable (§66). As mentioned, the force that concretizes the self's existence as a community member, is love: "Love founds a relationship that involves a liberation from abstract, isolated selfhood and the creation of genuine substantial independence as a determinate intersubjectivity or a corporate person" (Williams 214). Through love, we are compelled to actively respect and care for the rights and general well being of others, rather than simply being coerced into doing so through fear of punishment by the State.

${ }^{8}$ I would like to thank one of the anonymous reviewers on this essay for making this point. 
In Hegel's Philosophy of Right, love is founded in the institution of the family, through which individuals feel bonded as members of a whole (Hegel $P R \S 158$ ). It is in this unity that the family "instantiate the idea of a harmony that ethical life connotes" (Ormiston 83). There are two parts of the family: marriage and children. In the love that binds marriage, two persons "renounce their natural and individual personality to this unity of one with the other." Ironically, through "self-restriction" they obtain "substantive self-consciousness" (Hegel PR \$161). Implicitly, the ethical import of marriage is that the two are responsible for each other $(\S 163)$. But, the real ethical character of the family is found in the moral education of children, which aims at developing ethical values in the child "in the form of an immediate feeling for which differences are not explicit, so that thus equipped with the foundation of an ethical life, his heart my live its early years in love, trust, and obedience" (§175). By this, Hegel means that these ethical values are not rationally justified, but appeal to immediate feelings. Once they leave the family, however, these citizens must "rationally explicate" their values as they engage with others in civil society" (Ormiston 85). Nevertheless, the ethical foundations established through familial love, are still present in society. Moreover, Ormiston argues that this foundation makes civil society possible; without it, no one would feel bonded as a larger community. Thus, civil society presupposes the experience of love.

However, while the education of children in the family lays the groundwork for the realization of spirit, this is not to say that mutual recognition is expressed in the family. While loving, parents still have a disciplinarian relationship with their children (Hegel PR §174). Discipline is necessary since children initially exist in an instinctual state: "In respect of the same relation, this education has the negative aim of raising children out of the instinctive, physical, level on which they are originally, to self-subsistence and freedom of personality and so to the level on which they have power to leave the natural unity of the family" (\$175). Curiously, for Hegel, the educational and disciplinarian aspects of parenthood indicate that parents have more love for their children than children for their parents. This is because parental education fosters independence in children as they enter into a larger community. Parents, however, "possess in their children the objective embodiment of their union." This implies that parents love their children because they express the love of the couple. This point is crucial for understanding the difference between Levinas and Hegel respective view of familial life. For Hegel, parents love their children and feel responsible for their well-being because the latter objectively expresses the former's life. The love for the child can be reduced to the love of the couple. But, as we have mentioned, for Levinas children call parents to be responsible for their well-being through their very transcendence over and above the couple. This latter point will be addressed when we turn to Levinas' account of love. 
However, love is not just found in the Philosophy of Right. Ormiston argues that love implicitly determines the whole course of Hegel's thought. In his early theological writings, Hegel argues that love, rather than reflective rational thought, "constitutes the highest kind of knowing" (Ormiston 14). Unlike reflection, which produces dualities (subject and object), love realizes their unity, especially, the unity between the self and other, a necessity for ethics. Hegel finds this model of love in early Christianity.

Ethically, Christian love has two virtues. First, it overcomes the "clash of duties" that result from a moral system based on abstract, universal rules (16). Love "restricts itself in accordance with the whole of a given situation" (Hegel TW 294). Appealing to individual emotion, love calls us to behave within the particular context of the situation. Second, Christian love is necessarily communal; it is not love for the individual, but for all persons (Ormiston 17). For Hegel, the ethical idea of love revolves around the idea of "reconcilability." When one is harmed or have their rights infringed by another, they do not respond hostilely, but make no claim to being injured in the first place. Reconcilability is not a matter of forgiveness, but of turning the other cheek. For forgiveness implies that one feels harmed in the first place. The virtue of reconcilability is that it leaves open a space for someone to "reassume any vital relationship, to reenter the ties of friendship and love, since it has done no injury at all to life in itself" (236).

But, historically, this love failed. As Christianity grew, the community became less centered on the harmony of love, and more concerned with politics and theological issues of Christ's divinity. In becoming obsessed with the nature of Christ's being, love was overcome by reflective rationality (Hegel $T W 297$; Ormiston 24).

However, Ormiston will argue that the forgetting of Christian love sets the stage for Hegel's Phenomenology, claiming that the text is driven by the knowledge of love and that love realizes concrete recognition (36). Given our limited space, we will not be able to fully engage with Ormiston's reflections on the Phenomenology, instead we will examine the role of conscience, reconciliation and recognition as they relate to love. Conscience, for Hegel, is the concrete, internal sense that one is duty bound to perform a certain action, because they have the conviction that it is morally right (Hegel PS 393). As such, Ormiston argues the conscience is necessary for realizing the ethical life of Spirit, where the individual sees themselves as morally obligated for the well-being of others in the State (Ormiston 45). Moreover, because conscience unites universal law and particular actions, it also fulfills the function of Hegelian love (46).

However, conscience by itself, does not realize the full unity of love. At first there is division. The self wants their moral convictions to be 
recognized by the other. To be self-certain of their actions, the "I" "declares" his convictions to the other (Hegel PS 396). But rather than being affirmed, the other (the judging conscience) declares the motives of the "I" to be selfish, rather than for universal good (404). From here, the "I" has another realization: that they have played the role of judging conscience towards others as well. In order for their conscience to be positively recognized, they must admit their particularly and ask for forgiveness from the other; who in turn does the same. The possibility for mutual recognition, as moral actors, requires reconciliation "between the self and other, both forgiven for their selfishness" (Ormiston 53). Thus, reconciliation is "a reciprocal recognition which is absolute Spirit" (Hegel PS 408).

As a mode of love, not to dissimilar from reconcilability, reconciliation realizes the ethical life of Spirit and the mutual recognition between citizens as moral actors. Levinas' criticism that the force of Hegel's "impersonal reason" squashes the individual is unfair to the role that love plays in constituting the state as ethical society. The Spirit of the State does not force the individual into a totality in which their ethical relationships with others are nullified, but is itself the concrete manifestation of these relationships.

\section{Levinasian Love}

Nevertheless, there is still a problem with Hegelian love from a Levinasian perspective. For this love is really a narcissistic self-love - the love of the same. It is not the love for the other as Other. This is reflected in Hegel's appeal to the Christian dictum that we must "Love thy neighbor as thyself," which Hegel interprets as meaning, "love is a sensing of a life similar to one's own, not stronger or a weaker one" (Hegel TW 247). Thus, in loving the other, I reduce them to my self, which for Levinas is unethical.

Moreover, while perhaps not totalitarian, at least in origin, the actualization of spirit does produce a totality that stands over and above the individual. Indeed, reconciliation actualizes absolute spirit in a singular or individual entity that stands above the mutually recognizes members a community. Hegel writes, "The word of reconciliation is the objectively existing spirit, which behold the pure knowledge of itself qua universal essence, in its opposite, in the pure knowledge of itself qua absolutely self-contained and exclusive individuality - a reciprocal recognition which is absolute spirit" (Hegel PS 408). Reconciliation, as love, constitutes a singular, total community that stands above the singular "I." 
Indeed, Hegel argues that the individual "I" becomes less significant as spirit becomes more universal. Accordingly, Hegel claims that the individual "I" must thereby come to forget him or her self in the realization of spirit (45). Thus, while love builds a community and realizes absolute spirit for Hegel, this love also produces a situation that absolves the "I" of their significance. This consequence is radically unethical from a Levinasian perspective, given that the irreducibility of the Other and "I" is the very condition for the possibility of ethical responsibility. In light of these objections, then, we can develop an account of Levinasian love.

However, the status of love in Levinas' work is problematic and fraught with ambiguity. In a later interview, for example, Levinas claims that the very word "love" is "worn-out and debased" (Levinas EN 103). In an earlier essay, The Ego and Totality, Levinas argues that love concerns the "closed (intimate) society" of the couple, thereby negating society as such (Levinas CP 32). This is echoed in Totality and Infinity, where Levinas articulates the phenomenon of love in terms of the erotic relationship between the "I" and beloved. Accordingly, from a Levinasian perspective, love could not constitute Hegel's ethical community. In fact, Levinas would argue that this kind of love would negate the very possibility of justice, and therefore ethical responsibility.

Levinas argues that to "pardon," or forgive, is impossible. The idea of the pardon presupposes the closed society, which is to say that the pardon is only possible for the couple. The offender assumes that the wronged person has the capacity to totally pardon the offense. The problem is that pardoning excludes the existence of the third-party, or Others outside of the couple (Levinas $C P$ 30). This exclusion of the thirdparty, and by extension society as a whole, constitutes an injustice. Levinas writes, "The intimate society which makes pardon possible frees the will ("I") from the weight of the acts which escape it and engage it, and through which, in a real society, every will runs the risk of alienation" (31). The offender cannot really be pardoned since their wrong is never done to just one Other, rather it permeates social reality. In fact, against the "I's" intention, an injustice to an Other may extend not only to the whole of society, but for generations to come. Levinas claims, "the social wrong is something committed without my knowledge, against a multitude of third parties whom I will never face, whom I will never find in the face of God, and for whom God cannot answer" (33). Thus, justice cannot come from the love of couple that naively assumes that they can pardon and be pardoned. Hegelian love, in the form of forgiveness, constitutes an injustice.

But, Levinas' account of love is not entirely negative. In a later interview, Levinas expresses the possibility of a "love without concupiscence," which describes the ethical responsibility for the Other (Levinas EN 103). Levinas identifies this version of love with "agape" 
(113). However, as John J. Davenport points out, Levinas does not outline an "agape theory of ethics," although a general account of agape can be drawn out (Davenport 334). For Levinas, agape is a love for a "neighbor" or even a "stranger."

The "neighbor" plays a significant role in Levinas' thought to the extent that it is the ethical response to the face that constitutes the Other as neighbor: "It is precisely in this call to my responsibility by the face that summons me, that demands me, that claims me - it is in this questioning that the other is my neighbor" (Levinas NE 146). To love a "neighbor" therefore already implies a kind of love that respects the transcendence of the Other. Likewise, Levinas calls the love from the "stranger to stranger" ethically higher than even the communal "brotherhood" found in society (199). Levinas' proposed ethical love is therefore not something that seeks to create holistic community, like Hegel, rather it preserves the irreducible transcendence of both the "I" and Other such that both are strangers to one another.

In keeping with his emphasis on transcendence, Levinas states that there is a strict separation between ethical (agape) and erotic love, and neither are derived from each other: "...I think in any case that Eros is definitely not Agape, that Agape is neither a derivative nor the extinction of love-Eros" (Levinas EN 113). But, Linnell Secomb questions Levinas' divide between the two forms of love, appealing to literary examples that reveal the unity between the two (Secomb 64). Taking her cue, we will argue that, while ethical love is a not derivative of the erotic, they are compatible insofar as erotic love can enable and foster the ethical, encompassing more than the couple, but society as such. Moreover, Levinasian love can account for both familial love and Hegelian reconciliation, while still preserving the alterity of the Other.

For Levinas, erotic love is "equivocal par excellence" (Levinas TI 225). "Love remains a relation with the Other that turns into need, and this need still presupposes the total, transcendent exteriority of the other, of the beloved" (254). Hence, one the one hand, there is an "identity of feeling" between the lover and the beloved such that they achieve some unity (Mensch 156; TI 265). This produces the "closed society" that we previously spoke about. On the other hand, the Other cannot be reached erotically, and they remains a "virgin" (Levinas TI 258). Thus, "In voluptuosity (sexual pleasure) the other is me and separated from me" (265). Accordingly, Levinas calls this erotic love "dual egoism," since each "I" attempts to reduce the Other to themselves, which the Other simultaneously resists (266). However, this erotic coupling positively results in the birth of "the child," who calls the couple out of their egoism, moving the erotic to the ethical [266]. How does this child accomplish this? 
The birth of the child continues and expands society. As such, Levinas calls "fecundity" (the capacity of have children) a "new ontological principle" (276). It is new insofar as it breaks with the traditional totalizing view ontology, best expressed in Parmenides, where being is the One, or the same (Mensch 157). In fecundity, the "I" and the Other are able to produce a new being that did not exist in the given totality. Thus, fecundity constitutes a radical multiplicity, the excess of society that cannot be subsumed by the State. Moreover, since the child is Other, their life cannot be totally determined by the parent; their future is "beyond the possible, beyond projects" (Levinas TI 267). Accordingly, the fecundity of erotic love reveals, "otherness is prior to identity." That is, "alterity, which is composed of myself and the Other... cannot be composed into a unity; neither can the alterity that links the parent to the child" (Mensch 158). Against Hegel, even the family contains a fundamental alterity.

Fecundity has a profound moral dimension. First, in fecundity the Desire to good for the Other is partially satisfied: "Fecundity engendering fecundity accomplishes goodness" (Levinas TI 269). It does so, Mensch explains, "by engendering individuals that can be morally good" (Mensch 159). In short, fecundity produces the possibility for further acts of goodness and the expansion of ethical responsibility. Second, by producing a new Other, that is a new transcendent Face, parents are brought out of the dual egoism that exemplifies, calling them to become responsible for the life of the Other.

Fecundity produces a "unique" child, a separated "I." But they are not numerically unique, for there are other equally "unique" children produced from other families. This multitude of "I's" are brought into an ethical "face-to-face" relationship with each other, as "brothers among brothers" (Levinas TI 279). He calls this relationship "fraternity:" "fraternity is the very relation with the face in which at the same time my election and equality, that is, the mastery exercised over me by the other, are accomplished" (279). Fraternity is then the ethical responsibility for Others. ${ }^{10}$ What is important here, though, is to realize that fecundity and fraternity make society possible for Levinas. With his emphasis on a radical asymmetry it is difficult to see how a practical social life, in which people have some sense of solidarity, would ever be constituted. But, as

\footnotetext{
${ }^{9}$ While fecundity most obviously refers to the capacity to give birth to a child, this is not only what fecundity designates. Via the child, fecundity refers to the potential for birthing new instances of goodness, responsibility, justice, teaching, love and being.

${ }^{10}$ This appears to be the case in Totality and Infinity. However, as we have mentioned, in Entre Nous, Levinas seems to place the love of the Stranger higher than brotherhood (Levinas $N E$ 199). We can perhaps take this to mean that the love of the stranger is what we should strive for, but love in terms of fraternity is nonetheless necessary for some social cohesion.
} 
Mensch puts it, fraternity is " a relation involving the equality and the solidarity of our being for one another" (Mensch 167). Thus, fraternity constitutes the "social order" and makes something like a "We" possible (Levinas TI 280).

Fraternity "opens the erotic upon a social life" (280). It must be, then, that the ethical relationship with the Other, reflected in society, is attributed to the fecundity of the family. Like Hegel, ethics is intrinsically connected to and founded on familial love. But Levinas' account is radical insofar as he does not simply speak of the ethical love of the child by the parent, insofar as the former commands the responsibility of the latter (279), but also the erotic love that produces the child. And, it is through this latter sense that there is a potentiality for future manifestations of goodness and justice.

In contrast to his earlier indictment of the very possibility of pardoning or forgiveness, Levinas' account of erotic love is able to account for this phenomenon. Accordingly, erotic love constitutes something like Hegelian reconciliation. History cannot be a totality insofar as fecundity produces new generations who have the freedom to reassume or forgive the historical actions of their forbearers. Unlike Hegel's history, which is continuous, fecundity results in a "discontinuous time" that "makes possible an absolute youth and recommencement" (282). The deeds of the past - violent deeds - are not of this generation, and they do not have to "bear the guilt for them" (Mensch 170). In terms of reconciliation, this discontinuity makes it possible for generations to "pardon" and forgive the actions of the past (Levinas TI 282-283). Accordingly, the past instances of injustice that fragment society can be reconciled. Thus, Levinas' forgiveness is more expansive than Hegel's reconcilability by emphasizing that it does not simply reconcile persons or a community, but whole generations, while nonetheless preserving the alterity of the Other.

\section{Conclusion}

Both Levinas and Hegel recognize the ethical import of love. For Hegel, love makes mutual recognition possible, but not the legal recognition as a citizen; rather it is the recognition of the individual as a morally responsible agent of the State. The State is transcendent over the individual, but is concretized through the free actions of the citizen, founded on love. Indeed, in unifying the self and other, love is origin of the "We." But, it is precisely this point that Levinas would oppose. For Levinas, the unifying conception of love threatens the asymmetry between the Self and the Other that is necessary for ethical responsibility. This Love is devalued by Levinas as reflecting the "closed society" of erotic love. However, he later speaks of a "love without concupiscence," 
(Levinas EN 103) which cannot be the same as "love the other as yourself," for the neighbor is encountered in the Face of the transcendent Other. But, as has been argued, erotic love is compatible with ethical love, insofar as it produces future generations, or Faces, that are ethically responsible to each other. Fecundity contains the potential for infinite expressions of goodness.

Levinas' view of love has a greater potential for ethical responsibility than Hegel. While both see the family as the central to fostering societal love, Levinas is more radical due to the fact that he emphasizes parental love, while also reflecting on erotic love as engendering further expression of love. Moreover, this love allows for reconciliation, among generations rather than individuals in a state. However, we can also argue that Levinasian love for the Other, is the love for the "Stranger" as such (Levinas TI 39). As has been mentioned, Levinas claims that the love for the Stranger is the higher than the love found in brotherhood, or, in the language of Totality and Infinity, fraternity (Levinas NE 199). The implication of this claim is that ethical love, or agape, comes in at least three forms.

Ethical love can take shape as the love of the parent for their child, fraternal love and the love of the stranger. The first two are most obviously connected to the erotic. Through erotic love, the parent produces a child who commands the former's love, in terms of protective responsibility. Transcending the singular family, the erotic engenders the ethical love found in fraternity or brotherhood, which constitutes a social "We" who are bonded by their mutual Desire to do justice for one another. This kind of love is of course necessary to the extent that the "I" alone cannot live without the aid of Others. The love of the Stranger as such is higher than fraternal or familial love, insofar as the Stranger is absolutely irreducible to the family or society, and thus the erotic as well. It is precisely in the face of the Stranger that one can discover the most radical character of Levinasian love over that of Hegel. Hegel's love necessarily seeks unity, but this encounters problem when the Other does not wish to be subsumed in a given community. In other words, the problem with Hegel's account is that someone might not want to recognize or be recognized at all, thereby rupturing the desired unity that mutual recognition is meant to achieve. Levinasian love, however, is both engendering of society, or a "We," while nonetheless preserving the freedom of the Other to choose to not be a "We." In Levinas' words, the "Stranger also means the free one" (Levinas TI 39). ${ }^{11}$

${ }^{11}$ I would like to thank the anonymous reviewers at PhanEx for all of the helpful points they gave me to improve this paper. 


\section{Works Cited}

DAVENPORT, John J. "Levinas' Agapeistic Metaphysics of Morals: Absolute Passivity and the Other as Eschatological Hierophany." The Journal of Religions Ethics, Vol. 26. No. 2 (1998). p. 331-366.

Hegel, Georg W. F. Philosophy of Right (PR). Trans. T. M. Knox Oxford: Clarendon Press, 1965.

-. Early Theological Writings (TW). Trans. T. M. Knox. Philadelphia: University of Pennsylvania Press, 1971.

-. Phenomenology of Spirit (PS). Trans. Arnold V. Miller and J. N. Findlay. Oxford, England: Clarendon Press, 1977.

KoJÈVE, Alexandre. Introduction to the Reading of Hegel: Lectures on the Phenomenology of Spirit. Ithaca, New York: Cornell University Press, 1989.

LEVINAS, Emmanuel. Totality and Infinity: An Essay on Exteriority (TI). Trans. Alphonso Lingis, Pittsburgh, PA: Dusquesne University Press, 2008.

-. Otherwise than Being or Beyond Essence (OB). Trans. Alphonso Lingis. Pittsburgh, PA: Duquesne University Press, 2011.

- Collected Philosophical Papers $(C P)$. Trans. Alphonso Lingis. Dordrecht, The Netherlands: Nijhoff, 2000.

-. Entre Nous: On Thinking-of-the-Other (EN). Trans. Michael B. Smith and Barbara Harshav. New York, NY: Columbia University Press, 1998.

Mensch, James R. Levinas' Existential Analytic: A Commentary on Totality and Infinity.Evanston, Illinois: Northwestern University Press, 2015.

Moyn, Samuel. Origins of the Other: Emmanuel Levinas Between Revelation and Ethics. Ithaca, New York: Cornell University Press, 2005.

Ormiston, Alice. Love and Politics: Re-Interpreting Hegel. Albany: State University of New York Press, 2004.

Secomb, Linnell. Philosophy and Love: From Plato to Popular Culture. Edinburgh University Press, 2007. Web. 24 Nov. 2015.

WILliams, Robert R. Hegel's Ethics of Recognition. Berkeley, CA: University of California Press, 1997. 